\title{
COVID-19: Is herd immunity the answer?
}

\author{
Jared Robinson', Indrajit Banerjee1", Brijesh Sathian²
}

'Sir Seewoosagur Ramgoolam Medical College, Belle Rive, Mauritius

${ }^{2}$ Department of geriatrics and longterm care, Rumailah Hospital, Doha, Qatar

Keywords: Antibody-Dependent Enhancement, COVID-19 pandemic, Immune System Phenomena, Immunity, Nepal

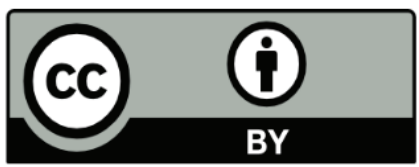

This work is licensed under a Creative Commons Attribution 4.0 Unported License.

\begin{abstract}
The current global figures of COVID-19 is still rising. Many countries have enforced lockdowns to safeguard its citizens, however in most cases this has been to the dire detriment of the economy. Most leaders and governments have been holding out and looking to the development of a vaccine to be the answer to this COVID-19 pandemic, however at this point in time and for the foreseeable future a viable and widely available vaccine is not likely to be developed. In juxtaposition to the conventional methods countries such as Singapore, Israel, Iceland, Portugal, The Netherlands, Sweden, Hong Kong, Japan, South Korea, Indonesia, Taiwan and Turkey have adopted the concept of herd immunity. It is there for poignant and of the upmost importance that an alternate stratagem is developed and exercised to best facilitate the re-ignition of the country's economy as well to best protect its citizens from the virus. Models such as herd immunity or a model based thereon are the most logical solution to attain this goal.

At this time in the development of the global COVID-19 pandemic it is too early to conclude as to whether a fullyfledged lockdown is more effective and useful than the establishment of herd immunity. In order to achieve the goal of safeguarding the lives of a countries citizens as well as its economy, a mixed method of lockdown and herd immunity is advised. Individuals who are economically active and less susceptible to the virus should adopt the herd immunity model, whereas those who are elderly with concomitant comorbidities should exercise self-isolation and follow the lockdown model. The application of using both models simultaneously, will both capitalize on the advantages of either and negate the drawbacks thereof. This ultimately decreasing the loss of lives whilst still inducing a degree of herd immunity within the general populous.
\end{abstract}

\section{Viewpoint}

The SARS-CoV-2 virus has been trans missed across the planet, with a current global total of a staggering 30,675,675 confirmed cases. ${ }^{1,2}$ The novelty, speed and ease of transmission of the virus has acted as the catalyst for the implication of both standard protocols as well as newly developed policies in order to combat and abate the transmission thereof. ${ }^{3,4}$

\section{Conventional measures:}

The measures introduced by the vast majority of countries are to

\author{
*Corresponding Author: \\ Dr. Indrajit Banerjee \\ Associate Professor \\ Department of Pharmacology \\ Sir Seewoosagur Ramgoolam Medical College, Belle Rive, Mauritius \\ $+230-58832236$ \\ indrajit18@gmail.com \\ Orcid id: https://orcid.org/0000-0003-2880-4695
}


the nature of the invocation of national restrictions of movement, under various acts such as the Public Health (Control of Disease) Act 1984 (England). ${ }^{5}$ Lockdown laws with social distancing as well the closure of schools and institutions which house a high-density population mass, have been the mainstay protocol employed by governments.

\section{Countries exercising herd immunity:}

In juxtaposition to the conventional methods countries such as Singapore, ${ }^{6}$ Israel, ${ }^{7}$ Iceland, ${ }^{8}$ Portugal, ${ }^{9}$ The Netherlands, ${ }^{10}$ Sweden, ${ }^{11}$ Hong Kong, ${ }^{12}$ Japan, ${ }^{13}$ South Korea, ${ }^{14}$ Indonesia, ${ }^{15}$ Taiwan ${ }^{16}$ and Turkey have adopted the concept of herd immunity. ${ }^{17}$ The implementation of herd immunity within these respective countries is unique and various aspects of the concept have been individually applied. The concept of herd immunity has therefore been tailored in order to suit its individual country's needs. Herd immunity is an epidemiological theory which acts on the basis of using the individuals within a population to prevent the further spread and transmission of a disease within the populous. Herd immunity can only be exercised when a sufficient number of individuals within the population have both acquired the disease agent and have subsequently developed immunity there to. The immunity that does therefore exist within the population reduces the likelihood of a diseased individual coming into contact with a susceptible individual and thereafter successfully transmitting the pathogen. ${ }^{18-20}$

\section{COVID-19 in Sweden, The United Kingdom and Germany:}

Sweden is viewed as the model for the application of herd immunity in the setting of COVID-19 as the Swedish government altered very little in the day to day routines of its citizens. Sweden's first case of COVID-19 coincides with the United Kingdom's index case which was reported to be on the 11th of March 2020. ${ }^{21,22}$ The United Kingdom initially attempted to implement herd immunity into its populous, however after running simulations and concluding that its health system could not absorb the projected figures it initiated a temporary lockdown.

The Swedish government, however made every citizen responsible for the maintenance of their personal health. It implemented social distancing and stringently advised the elderly to remain at home. Any individual presenting with symptoms was expected to exercise self-isolation. In absolute contradiction to international convention Sweden's preschools and schools remained operational. ${ }^{23,24}$

A comparison between England's lockdown and Sweden's herd immunity using a comparative interrupted time series analysis by Ali and team suggests that lockdowns do reduce new cases more effectively than the herd immunity model as the new case rate in England during the lockdown period was reduced by 19 cases per $10,000,000$ people as when compared to Sweden. ${ }^{25}$ Although Sweden's stance is liberal and its deaths per capita due to COVID-19 are ranked 9th highest in the world (57.3/100 000 people), The United Kingdom's deaths per capita are ranked as the 5 th highest (62.6/100 000 people). The fatality rate witnessed in Sweden is $6.9 \%$ almost half that of the $12.9 \%$ documented in The United Kingdom. ${ }^{26}$ It is therefore evident that despite Sweden's liberal stance and high rates, it still suffered less than other countries which exercised severe lockdowns. As of the 18th of September 2020, Sweden has a total of 87,885 confirmed cases with a death count of 5864, whereas The United Kingdom has a total of 381618 confirmed cases with a loss of 41705 lives. $^{2}$

On comparing Sweden's deaths to Germany's per gross population, Sweden had thrice the amount of deaths (2679 deaths per 10000 000) as when compared to Germany (6848 deaths per 80000
000). The authority of Health in Sweden "Folkha Isomyndigheten" incorrectly stipulated that the curve had reached its summit on the 15th of April 2020 as new cases broke this threshold shortly thereafter. The situation in Sweden is just as unpredictable as the global situation and Sweden's normalized death rate is currently higher than that of Germany's. ${ }^{27}$

\section{Pitfalls of herd immunity:}

The principle of herd immunity and the degree to which it can play a role within a set populous is dependent on the infectivity of the disease agent. If the disease agent is highly contagious and easily transmissible it makes the establishment of herd immunity more challenging as a higher percentage of the population need to become immune to the disease for true herd immunity to be established and subsequently be effective. Gavi, the vaccine alliance estimate that at least $60 \%$ of the population will need to contract and become immune to COVID-19 in order for the herd immunity model to be effective..$^{28}$ The intrinsic flaw with this model is that it takes time for herd immunity to develop and hence the casualties because of this delay will be higher.

\section{Advantages of herd immunity:}

Herd immunity which is not reliant on vaccination, is both a cost effective and relatively simple method in which the general populous can be protected from a disease agent. The body's natural defence mechanisms are employed and used to provide this protection. Although it takes time, once herd immunity is established it is lifelong within the immune individuals. Herd immunity is still an effective mechanism even if some individuals within the population group are susceptible to the disease agent. ${ }^{29}$

\section{Application of herd immunity in Nepal:}

Nepal has a population of 29255514 , with the median age being calculated to be 24.6 years. ${ }^{30-31} \mathrm{Nepal}$ has therefore got a younger populous and thus, the establishment of herd immunity would be advantageous as the country would quickly regain its economic driving force and thus further damage to the economy and the livelihood of the nation's people would be circumvented; furthermore the younger age of the populous would translate to lower deaths in gaining the herd immunity as the elderly are most susceptible. The benefits in the case of Nepal of establishing herd immunity would outweigh the detriments. Nepal's establishment of herd immunity would be an easier task as opposed to establishing herd immunity in a country such as Sweden where the median age is 41.2 years. ${ }^{30}$

\section{Conclusion:}

The global battle against COVID-19 is currently underway and although Sweden has been scrutinized by many for its stance and use of the herd immunity principle; it has also drawn much praise by the likes of Michael J. Ryan, The Chief Executive Director of the World Health Organization Health (WHO) Emergencies Programme. Dr Ryan eluded to the fact that Sweden's governing and handling of the pandemic may act as a global blueprint in future.

At this time in the development of the global COVID-19 pandemic it is too early to conclude as whether a fully-fledged lockdown is more effective and useful than the establishment of herd immunity. Governments walk a fine line between lockdown and the safeguarding of food security as well as the country's economy. At this current point in time no vaccine is available and won't be available for the foreseeable future. It is therefore imperative that countries minimize the economic damage as well as minimize the loss of lives of its citizens. In order to achieve the goal of safeguarding the lives of a countries citizens as well as 
its economy, a mixed method of lockdown and herd immunity is advised. Individuals who are economically active and less susceptible to the virus should adopt the herd immunity model, whereas those who are elderly with concomitant comorbidities should exercise self-isolation and follow the lockdown model. The application of using both models simultaneously, will both capitalize on the advantages of either and negate the drawbacks thereof. This ultimately decreasing the loss of lives whilst still inducing a degree of herd immunity within the general populous.

\section{References}

1. Guo YR, Cao QD, Hong ZS, Tan YY, Chen SD, Jin HJ, et al. The origin, transmission and clinical therapies on coronavirus disease 2019 (COVID-19) outbreak - an update on the status. Mil Med Res. 2020;7(1):11. https://doi.org/10.1186/ s40779-020-00240-0

2. WHO Coronavirus Disease (COVID-19) Dashboard. [online 2020] [cited 2020 Sept15] Available from: URL:https:// covid19.who.int/

3. Dickens B L, Koo JR, Lim JT, Park M, Quaye S, Sun $H$ et al., Modelling lockdown and exit strategies for COVID-19 in Singapore. The Lancet Regional Health - Western Pacific, 2020; 1, 100004. https://doi.org/10.1016/j. lanwpc.2020.100004

4. Galea S, Merchant RM, Lurie N. The Mental Health Consequences of COVID-19 and Physical Distancing: The Need for Prevention and Early Intervention. JAMA Intern Med.2020;10.1001

https://doi:10.1001/jamainternmed.2020.1562

5. England: Legal Responses to Health Emergencies. [online 2020] [cited 2020 Sept21] Available from: URL: https://www. kingsleynapley.co.uk/insights/blogs/criminal-law-blog/ covid-19-the-legal-basis-for-lockdown

6. Lai L. Coronavirus: Singapore has chance to slow down spread of virus, says Gan Kim Yong. The Strait Times. 2020. [online 2020] [cited 2020 Sept21] Available from: URL:

https://www.straitstimes.com/politics/spore-has-chanceto-slow-down-spread-of-virus-gan

7. Yeheskeli DY. Israel must turn to herd immunity to combat coronavirus. Y Net News. 2020Mar 31. [online 2020] [cited 2020 Sept 21] Available from: URL:

https://www.ynetnews.com/article/H1BMnA6UL

8. Hafstað V. Herd Immunity Threshold Could Be Lowered in Iceland. Iceland Monitor. 2020. [online 2020] [cited 2020 Sept 21] Available from: URL:

https://icelandmonitor.mbl.is/news/news/2020/03/26/ herd_immunity_threshold_could_be_lowered_in_iceland/

9. Demony C, Waldersee V. Portugal restricts movement to stem coronavirus, rules out rationing. $20202 \mathrm{Mar} 19$. [online 2020] [cited 2020 Sept 21] Available from: URL:

https://www.usnews.com/news/world/ articles/2020-03-19/portugal-restricts-movement-to-stemcoronavirus-rules-out-rationing

10. Shields B. Dutch embrace 'herd immunity' as dire death warning prompts UK to change course. Sydney Morning herald. 2020 Mar 17. [online 2020] [cited 2020 Sept21] Available from: URL: https://www.smh.com.au/world/europe/dutch-embraceherd-immunity-as-dire-death-warning-prompts-uk-tochange-course-20200317-p54arv.html

11. Henley J. Swedish PM warned over 'Russian roulette-style' Covid-19 strategy. The Gardian. [online 2020] [cited 2020 Sept21] Available from: URL:

https://www.theguardian.com/world/2020/mar/23/ swedish-pm-warned-russian-roulette-covid-19-strategyherd-immunity

12. News RE. Full lockdown not needed in Hong Kong: HKU professor 2020 Mar 27. [online 2020] [cited 2020 Sept21] Available from: URL:

https://news.rthk.hk/rthk/en/component/k2/151714820200327.htm

13. Asia. Coronavirus: How Japan keeps COVID-19 under control. [online 2020] [cited 2020 Sept21] Available from: URL:

https://www.dw.com/en/coronavirus-how-japan-keepscovid-19-under-control/a-52907069

14. News BBC. Coronavirus: South Korea reports lowest number of new cases in four weeks 2020 Mar 23. [online 2020] [cited 2020 Sept21] Available from: URL:

https://www.bbc.com/news/world-asia-52001837

15. writers Ns. From light touch to total lockdown: How Asia is fighting coronavirus. Asian Review. 2020 Mar. [online 2020] [cited 2020 Sept 21] Available from:

https://asia.nikkei.com/Spotlight/Coronavirus/From-lighttouch-to-total-lockdown-How-Asia-is-fighting-coronavirus

16. Yun M. How Taiwan is containing coronavirus - despite diplomatic isolation by China. The Gardian. 2020 Mar 13. [online 2020] [cited 2020 Sept 21] Available from:

https://www.theguardian.com/world/2020/mar/13/howtaiwan-is-containing-coronavirus-despite-diplomaticisolation-by-china

17. Chotiner I. The Coronavirus Meets Authoritarianism in Turkey. The New Yorker. 2020. [online 2020] [cited 2020 Sept 21] Available from:

https://www.newyorker.com/news/q-and-a/thecoronavirus-meets-authoritarianism-in-turkey

18. Smith DR. Herd Immunity. Vet Clin North Am Food Anim Pract. 2019;35(3):593-604. https://doi:10.1016/j. cvfa.2019.07.001

19. Alam MJ, Rahman MF. Herd Immunity: A Brief Review. Mymensingh Med J. 2016;25(2):392-395.

20. Mallory ML, Lindesmith LC, Baric RS. Vaccination-induced herd immunity: Successes and challenges. J Allergy Clin Immunol. 2018;142(1):64-66. https://doi:10.1016/j. jaci.2018.05.007

21. Bhopal RS. To achieve "zero covid" we need to include the controlled, careful acquisition of population (herd) immunity. BMJ. 2020;370:m3487. https://doi:10.1136/bmj. m3487

22. Easom N, Moss P, Barlow G, et al. Sixty-eight consecutive patients assessed for COVID-19 infection: Experience from a UK Regional infectious diseases Unit. Influenza Other Respir Viruses. 2020;14(4):374-379. 


\section{https://doi:10.1111/irv.12739}

23. Gémes K, Talbäck M, Modig K, et al. Burden and prevalence of prognostic factors for severe COVID-19 in Sweden. Eur J Epidemiol. 2020;35(5):401-409. https://doi:10.1007/s10654020-00646-z

24. Pierre J. Nudges against pandemics: Sweden's COVID-19 containment strategy in perspective, Policy and Society, 2020; 39:3, 478-493.

https://doi:10.1080/14494035.2020.1783787

25. Ali MM, Samhouri Y, Sabha M, Alnimer L. England's Lockdown vs. Sweden's Herd Immunity: A Comparison of the Daily New COVID-19 Cases and Related Deaths Using Comparative Interrupted Time Series Analysis. medRxiv. 2020 Jan 1.

26. Orlowski EJW, Goldsmith DJA. Four months into the COVID-19 pandemic, Sweden's prized herd immunity is nowhere in sight. J R Soc Med. 2020;113(8):292-298. https:// doi:10.1177/0141076820945282

27. Jung F, Krieger V, Hufert FT, Küpper JH. Herd immunity or suppression strategy to combat COVID-19. Clin Hemorheol Microcirc. 2020;75(1):13-17.

https://doi:10.3233/CH-209006

28. What is herd immunity? [online 2020] [cited 2020 Sept 21]
Available from: https://www.gavi.org/vaccineswork/whatherd-immunity

29. Pérez-Trallero E, Cilla G, Urbieta M. Rubella immunisation of men: advantages of herd immunity. Lancet. 1996;348(9024):413.

https://doi:10.1016/s0140-6736(05)65039-8

30. Nepal Population (LIVE). [online 2020] [cited 2020 Sept 21] Available from: URL:https://www.worldometers.info/worldpopulation/nepal-population/

31. Banerjee I, Robinson J, Kashyap A, Mohabeer P, Shukla A, Leclézio A. The changing pattern of COVID-19 in Nepal: A Global concern- A Narrative Review. Nepal J Epidemiol. 2020;10(2):845-855.

https://doi:10.3126/nje.v10i2.29769 